\title{
A Link To The Future: A Pilot Study Look At How Historically Black Colleges And Universities With Journalism And Mass Communications Units Use The Internet In Recruiting
}

Jerry Crawford, II, University of Kansas, USA

\begin{abstract}
Historically Black Colleges and Universities (HBCUs) have had the ability to recruit AfricanAmerican students since the 1860s by stressing a sense of inclusion and family through their mission statements and community outreach. There was little to no competition for AfricanAmerican students from predominantly white institutions until integration was fully implemented a hundred years later in the 1960s. HBCUs, by their standing in the community, have been a gateway to first generation college students, regardless of race or social class status and "many continue to have 'open' admissions policies, welcoming all who wish to attend college, regardless of previous academic performance.

Today, HBCUs have to actively recruit students - students that can now apply and enroll in Predominantly White Institutions (PWIs) - with the use of technology that includes the Internet. How has the digital divide changed from its classification in the 1960s? How are AfricanAmericans using the web and are HBCUs using the Internet to inform, recruit and enroll AfricanAmericans today?

This pilot study looks at HBCUs that have Journalism/Mass Communications units to examine if their websites have a good sense of usability and interactivity for African-American students looking to go to college, primarily as first-generation students.
\end{abstract}

Keywords: HBCUs - Historically Black Colleges and Universities; PWIs - Predominantly White Institutions; Digital Divide - Term used to describe the technology/Internet gap between minorities and whites in America; Usability - The ease by which a user can navigate and access information on a website

\section{INTRODUCTION}

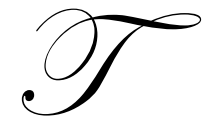

here are studies now that challenge the "need" for these institutions in 2011 and beyond in America. African-Americans can now enroll in any college or university they can qualify academically and afford to pay tuition. There are many different reasons that African-Americans look for today to make their college choice - other than the tradition of HBCUs. High school guidance counselors and pastors at the local church no longer are the primary focus of information for students looking to learn more about colleges. Technology allows prospective students to look deeper into a college and specifically, a program in which they are interested in pursuing than the brochure in the guidance office can contain. It should be noted that many firstgeneration hopefuls have not been encouraged to apply for college and "have little insight or experience with the process; and they may not know factors to consider in selecting a suitable college (Elam \& Brown, 2005). Colleges and universities are changing the way they market their programs and looking for innovative ways to recruit students 
by providing new linkages for everyone that normally plays an important role in the prospective students' choice to enroll into a specific school and to matriculate at that school. Cognitive responses are informative as they have been found to affect brand evaluations and those effects have been found to be persistent over time (Pomering \& Johnson, 2009).

Most students are still interested in affordability, financial aid, what courses are required, cultural/student organizations, career possibilities and living opportunities. One source of differences across groups in collegerelated outcomes is knowledge about college and financial aid. But, research also shows that a lack of knowledge about college, specifically financial aid, is prevalent in society today (Bell, Rowan-Kenyon \& Perna, 2009).

African-Americans may also be interested in such things as minority ratios within a school or program. They can look up this information on the Internet - primarily on each college's website and additionally on other informational sites. HBCUs now need to compete for these students. How do HBCUs persuade or influence students to enroll in their programs - what is the message, if any, central to their websites? Will it be the financial opportunities? The fear of not being able to afford college is real. "Schools can help reduce these anxieties by providing parents with informational sessions, newsletters, and websites on financial aid (Daigneault \& Wirtz, 2008). How about a solid career placement program? Many of these students will not have any insight as to how to walk through the maze of information. Often this lack of knowledge is most pronounced among Latino and Black students and parents, low-income parents (De La Rosa, 2006) and parents who have no direct personal experience with college, and students who aspire to attend a two-year versus a four-year institution (Bell, Rowan-Kenyon \& Perna, 2009).

This pilot study will look at six HBCUs that have journalism/mass communications units and how they use their websites as a means to provide information to prospective students. The study will look at each school's website usability matrix designed by Jakob Nielsen and if they contain 20 topics chosen as a way to measure this matrix. The schools were chosen in two groups - one group regarding size and the other group regarding in-state tuition rate. These schools will be able to represent the 49 total HBCUs that offer journalism/mass communication units in future research on this topic. The stakes are high for universities as institutions and HBCUs are no different in how they look to recruit applicants. The debate over admissions has attracted so much attention in recent years that it has encouraged a tendency in the public to forget that American universities have large social responsibilities. These responsibilities encompass far more than assessing the academic merits of individual applicants against each other (Atkinson \& Pelfrey, 2006).

This pilot study is important because HBCUs provide the majority of African-American journalists in America and democracy needs these diverse voices in the media and in society. This study also provides a basis for future study on HBCU website development and African-American students' Internet usage.

\section{LITERATURE REVIEW}

\section{Persuasive Messages}

There have been many studies that look at how messages are sent and received and how they are produced. This pilot study looks at how HBCUs use the medium of the Internet, specifically their journalism/mass communication unit's website, to persuade prospective students to apply for enrollment. HBCUs have to use their histories and their original missions and begin "treating communication as a mechanism by which message senders use their knowledge and skill to affect the understanding or behavior of message receivers toward predetermined goals (Shelby, 1998). In discussing how colleges and universities utilize the Internet, Matt Nathan, vice president of ePageCity says with schools, 'content is king'; in other words, school websites are more about information than marketing (Starkman, 2006).

Rhetoric produces temporally constrained truths arising from cooperative critical inquiry. No longer playing simple handmaiden to the grand truth, rhetoric is charged instead with "creating" multiple, situated truths (Rufo, 2003). Schools need to realize they have to market themselves and, using their own medium (website), they can control their brand better than ever. The college choice process received enormous attention in the past two 
decades. With the explosion of the Internet came the incorporation of the Web in this process. Researchers have consistently found that prospective students utilize the Web on an increasingly frequent basis (Poock, 2006). The information that is provided to the audience needs to be authentic, but will the audience listen? The ultimate result of marketing is an exchange. Exchanges, however, do not eventuate solely on the basis of the information a supplier disseminates (Pomering \& Johnson, 2009).

\section{College Websites: The Search Begins}

Poock and Lefond (2003) examined the characteristics of effective graduate school websites utilizing focus groups and surveys and Poock replicated this in 2005 (Poock, 2006). What is interesting is that undergraduate research shows the same results as those of graduate students. Additionally, Hoeflich (2002) surveyed new graduate students at a major research university. A consistent finding in these studies is that an institution's website is the dominant tool utilized by prospective graduate students (Poock, 2006).

African-American students looking at websites for colleges will not only be searching HBCUs, but also predominantly white institutions. What types of messages will these other institutions be sharing? Will they be similar? Are there different messages for African-Americans and Whites? Previous studies have been done on this. "Much of this research finds that Black consumers heavily rely on print and television for information and use that information when making purchases" (Appiah, 2003). College websites need to keep these differences in mind when they build their pages. As the Internet becomes more crowded and as Blacks increase use of and access to the Internet, content providers will need to know how best to reach both Black and White audiences. So, is it an economic or cultural difference in why there is a difference? Blacks with incomes below $\$ 40,000$ were far less likely than Whites to own a computer and go online for hours (Appiah, 2003). It is easy to surmise that AfricanAmericans with salaries "above $\$ 40,000$ are as likely or more likely than Whites to own a computer, have computer access at work, and use the Internet during office" (Appiah, 2003) It is almost impossible today to apply to any college without using a computer. In the past, students needed to be proficient in reading and writing. The norm now is to be proficient in computers - this will be "expected of incoming freshman in the 21 st century, so much so that technological access and proficiency have become a part of the skill set in the application process" (Richardson, 2008).

\section{African-American Internet Usage}

In 1968, Task Force on Violent Aspects of Protest for the National Commission on the Causes and Prevention of Violence, commonly known as the Kerner Commission Report, discussed the media divide between Whites and African-Americans. The report did bring to light how African-Americans and Whites used information with the "news media portrayed the 1967 riots as black-white conflicts rather than placing them in the context of people stressed by deteriorating economic and living conditions" (Mastin, 2000). The challenge in 2011 is in keeping democracy strong with full access for everyone with high-speed Internet connections. The Kerner Report was in response to what many thought was happening to America and said that the U.S. was heading toward 'two societies - one black, one white-separate and unequal' which hastened the nation's movement from antidiscrimination to affirmative action policies (Atkinson \& Pelfrey, 2006).

The 'digital divide' is most often used to refer to differential access to the Internet (Zimmerman \& Meyer, 2005). According to the organization Digital Partnership in Seattle, the term 'digital divide' was first coined during the debate over the Telecommunication Act of 1996 (Feldman, 2000, p. 55). As late as 1999, studies found the digital divide between (at least) urban African-Americans and Whites was still a large one. Just $11.8 \%$ of urban blacks had a computer in their homes, contrasted with 30.3\% of whites and $13.2 \%$ of Hispanics, said a 1999 report, 'Falling Through the Net (Dreyfuss, 2001). The National Telecommunications and Information Administration, as part of the Commerce Department, did that report. In a comment that is completely timely in 2011 with how HBCUs must be able to compete with other institutions, President Lyndon Johnson in 1967 asked, "Can we be 'completely fair' without attention to race and ethnicity, especially in access to education?" (Atkinson \& Pelfrey, 2006) The Digital Network, a coalition of the National Urban League and Benton Foundation, identifies the term digital divide as a "gap between those who can effectively use new information and communication tools, such as the Internet, and those who cannot" (Feldman, 2000, p. 55). 
Are there any changes in the digital divide since the 1960s? Other empirical studies indicate that there is virtually no difference in Internet use among Blacks and Whites with middle to upper level incomes and that Blacks are among the fastest growing segments on the World Wide Web (Appiah, 2003). The digital divide may have shortened, but there is a new challenge - an information literacy divide. Information literacy is the ability to recognize when information is needed and to locate, evaluate, and use the information. The skills divide replicates the access divide - those who lack skills tend to be older, less educated, poor, African-American, and Latino (Tapia \& Ortiz, 2008). This skill of being able to understand what information is "out there" and discern the use of clicking on video games on the web are two distinct differences. In America, African-Americans are using technology at even higher rates than Whites. A 2010 pewinternet.org study found African-Americans and Latinos continue to outpace Whites in their use of data applications on hand-held devices (Smith, 2010). This simply means AfricanAmericans are not aware of the capabilities of using the web or wireless Internet options. Studies show that $87 \%$ of Blacks and Hispanics own a cell phone, compared to $80 \%$ of Whites. Additionally, Black and Latino cell phone owners take advantage of a much wider array of their phones' data functions compared to White cell phone owners (Smith, 2010).

The question to answer now is, "How are African-Americans using the Internet?" A 2011 study by the Kaiser Family Foundation found that minority children spend an average of 13 hours a day using mobile devices and computers - about 4-1/2 hours more than White kids (Marcus, 2011). The study was done as a focus on obesity causes, but it clearly shows African-American children are now high-level users of the Internet. The study tracked children 8 to 18 years of age on their use of media. One of the results of the study is quite alarming. The research indicated that among all groups, computer playtime far outweighs homework, which accounts for only about 16 to 20 minutes a day (Marcus, 2011). This use of computers at home is staggering. It shows African-Americans have the opportunity to use these skills to expand their educational horizons, if mentored in this area. If not at home, then it would seem these same students would be able to get this guidance within the K-12 educational system. However, this is not the case; the technology access and use in U.S. schools is indeed somewhat polarized with schools serving Black, Hispanic, and low socio-economic status (SES) students tending to have the lowest access to, and the most remedial usages of, new technology. Reliance on high schools for information about college is problematic as often these same students attend inadequate high schools that provide minimal college guidance to students (Bell, RowanKenyon \& Perna, 2009).

\section{What makes a well designed website?}

Usability. In his book, "Designing Web Usability", Jakob Nielsen states, "The Web is the ultimate customer empowering environment. He or she that clicks the mouse gets to decide everything" (Nielsen, 2000). If a site is not immediately interesting or the audience is not impressed, that first impression is lasting. It is so easy to go elsewhere; all the competitors in the world are but a mouse click away (Nielsen, 2000).

The choice of a college in 2011 and beyond will continue to move away from the standard brochure, that a prospective student will see by chance at a college fair, to information they can acquire at their own pace and convenience. Nathan Gault, assistant director for technology support at Yale University, was surprised at the importance of a school's website, until he was speaking with a colleague. His daughter would visit an admissions home page, and if she couldn't find what she was looking for in five seconds, she would immediately click away (Feeney, 2009). In making a college choice, many African-American students use their perception and assessment of institutional quality, the financial-aid package, the academic programs offered, and the institutions' attempts to attract the student (Tobolowsky, Outcalt \& McDonough, 2005).

Students have iPads, smart phones and other mobile devices. As they begin their search for schools, many of them will simply log in and see the institution's website. So, what is the target audience? Is it the student? The parent? In 2001, Poock and Lefond studied college-bound high school students and found that virtually all of them relied upon the Web when applying to colleges or universities (Poock, 2006). Jami Silver is the assistant dean of admission at Wesleyan University and sees the changes that have occurred in college recruiting. More and more students are looking at colleges based on the Internet and more and more admissions offices are looking at the Internet as a tool, Silver said (Feeney, 2009). 
HBCUs need to use these basic design tenets and remember what is important for the students that are looking at them as primary college choices. Though many more African-Americans have computers and Internet options, the challenge of finding and paying for college is still paramount. Therefore, it is a combination of basic computer literacy and understanding of how funding works that many students and their parents lack the instrumental knowledge needed to efficiently navigate websites in order to gain information about, and apply for, financial aid (Bell, Rowan-Kenyon \& Perna, 2009). Venegas also found that school staff members lacked sufficient training to help students navigate on-line processes (Bell, Rowan-Kenyon \& Perna, 2009).

\section{METHODOLOGY}

\section{Subjects}

Several steps were taken to acquire an adequate sample of HBCUs that had units of journalism and websites. The first step was to identify the schools as being designated as an HBCU. The second step was to identify the HBCUs that offered any form of journalism/mass communication as a concentration, program, or degree option.

A subject sampling of 18 HBCUs was randomly selected from a population of 49 institutions with units that contained journalism tracks. The schools were chosen from a list of HBCUs from CollegeStats.org which categorizes the HBCUs by cost (in-state tuition - most, medium, least) and by size (largest, medium, low).

The decision to choose in-state tuition was due to the financial challenge most applicants face and the proximity to the "hometown" school. Size was chosen due to the fact that many students feel about attending large or small schools. HBCUs have, as part of their overall mission, a desire to nurture students and know the importance of a "strong, supportive campus, interpersonal relations and social networking for cognitive, intellectual, and careerrelated functioning of Black students on Black campuses" (Sissoko \& Shiau, 2005).

Random sampling has been applied to avoid bias in the selection of subjects by choosing a list of three each for high, medium and low from both categories and ensuring the choices were spread to all regions of the country that had these institutions. Attention was also given to not duplicate schools in more than one category. None of the single-sex institutions were included in the survey.

This pilot study used content analysis over a six-week period from May 15, 2011, through June 30, 2011. The HBCUs for this study are: In the size category of High (Florida Agricultural and Mechanical University, Tennessee State University, and North Carolina A\&T State University), Medium (Grambling State University, University of the District of Columbia, and Alabama State University), and Low (Talladega College, Edward Waters College, and Wilberforce University), and in the cost category of High (Clark-Atlanta University, Hampton University, and Bethune-Cookman University), Medium (Voorhees College, Lincoln University of Pennsylvania, and Jarvis Christian College), and Low (Elizabeth City State University, Albany State University, and Bluefield State College).

\section{Grounded Theory}

This study uses the grounded theory to look at the issue of website usability of Historically Black Colleges and Universities. Glaser and Strauss (1967) proposed a 'grounded' empirical data approach that would rely on 'sensitizing concepts' to guide theory development (Jensen \& Jankowski, 1991). This study looks at how HBCUs with journalism/mass communication units currently use their unit's home page. Grounded theory has a goal that accounts for a pattern of behavior that is relevant and problematic for those involved. The goal is not voluminous description, nor clever verification (Ekins, 1997, p. v).

The empirical data was observed over a six-week time period and was the continuation on research on HBCUs and their role in the future of journalism (Crawford, \& Hines, 2010). This research follows the Strauss model by which the researcher goes looking for the meaning data holds and goes beyond the superficial (Denscombe, 2007, p. 102). Using the data found on each of the HBCUs' websites created the possibility of analyzing where the HBCUs currently are with their information and marking. Grounded theory allows things like 
'coding paradigms' to provide a fairly extensive and detailed framework that is intended to help researchers make sense of the data; that is, to interpret the data in a systematic way (Denscombe, 2007, p. 102).

The sample size for this study was an issue due to the total number of prospective target HBCUs being small. Also, there was a time element to consider for data collection. The research focused on a core set of 20 subjects that were pertinent to the research and were observed over a six-week time period. It was from these observations that the coding was generated. Codes (labels) are inductively created by the researcher during repeated data readings. One does not examine whether predetermined concepts are in the text, as in a content analysis (O'Callaghan \& Hiscock, 2007).

\section{Coding}

Jakob Nielsen, who is considered the leading authority on web usability, says that content is the primary reason people visit and use a website. When users go to a page, they look immediately in the main content area and scan it for headlines and indications of what the page is about (Nielsen, 2000). This study wanted to determine the common elements on the HBCU websites and whether the websites have a commonality to what are considered. The home page is the key as the first immediate goal of any home page is to answer the questions, "Where am I?" and "What does this site do?" (Nielsen, 2000) Visitors from outside the site, once they are there, do not have to be reminded over and over where they are; "interior pages need to focus more on specific content and less on providing a general welcome or overview of the site (Nielsen, 2000).

Twenty different elements were coded - mission statement, financial aid/scholarship opportunities, curriculum, course schedule/graduation roadmap, menu bar location, menu bar construction, text size(s), search engine on home page, faculty listing, faculty vitae/web pages, career opportunities, social media links, student activities/organizations, student media, contact (other than webmaster), research opportunities, alumni, admissions information, logo/branding on page(s), and human images depicted (race, gender, dress, and activity).

Each of the six three-member groups was graded on a basic scale of (0) for none present, (1) for present but no interactivity, or (2) for present and functional. Interactivity is defined as allowing the person to access information and points to relevant information. If an element was more than three clicks away, the unit was given a 0 .

The six-week timeframe was used to allow for any instances by institutions to make regular updates on their websites and to also include the occurrences of graduations, summer school, and registration for the upcoming school year. The cycle of reflection, observation, and analysis is repeated until the theoretical formulations have exhausted the available data (Peters, \& Wester, 1990). A sample size of 18 of a universe of 49 possible institutions did show some trends within the coding.

\section{FINDINGS AND ANALYSIS}

The research for this pilot study was interested in finding African-Americans and other students interested in attending college at Historically Black Colleges and Universities. Eighteen HBCUs were monitored during a sixweek period and 20 different elements were examined to gain knowledge as to how HBCUs are using the Internet to recruit and interest prospective students. Studies found that African-American and other minority students are now heavy computer and mobile device users and "most potential students will view a website before they visit a campus. A dynamic website is a cost-effective way to increase visibility and to attract new students" (Malroutu \& Tripp, 2008).

HBCUs have a legacy of being seen as the best place to be nurtured as well as educated for AfricanAmericans. HBCUs have to compete with all other institutions and have the same educational responsibilities while remaining true and faithful to their traditional missions of service to students through access and service to the community through the contributions of educated citizens (Brown \& Freeman, 2004, p. 132). Are HBCUs using the web to further their goals? Almost all university and department websites now include space devoted to future students, explaining the advantages of studying at the university (Malroutu \& Tripp, 2008). 


\section{Mission Statement}

HBCUs have a legacy of over 155 years of being both educator and community pillars for AfricanAmericans. "HBCUs are facing a turning point as they strive to fulfill their missions while at the same time competitively prepare for the future" (Camp, Barden, Sloan \& Clarke, 2009). It is this challenge that drives this research. Have HBCUs lost their mission? This pilot study used, as one of its elements of web usability, the "mission statement." Mission statements have a variety of purposes; among them is that "a shared sense of purpose has the capacity to inspire and motivate those within an institution and to communicate its characteristics, values, and history to key external constituents" (Morphew \& Hartley, 2006).

This study found that half of the units (9 out of the 18) did not have a mission statement regarding what they strategically saw as their purpose to educate or nurture students. Table 1 shows the overall percentages of the results.

Table 1: Does the unit have a mission statement?

\begin{tabular}{lcc}
\hline & Frequency & Percent \\
None & 9 & 50.0 \\
Present & 1 & 5.6 \\
Functional & 8 & 44.4 \\
Total & & 100.0 \\
\hline
\end{tabular}

\section{Financial Aid \& Scholarships}

Most HBCUs have 70 to $85 \%$ of their students on some kind of financial aid. Problems have been legend in the distribution of these funds to the students (Evans, Evans \& Evans, 2002). A majority of first-generation college hopefuls have no idea how they will pay for college and they definitely do not know how to navigate through the maze; that is, the financial aid office. This study found that only three of the 18 units had a functionally available link to financial aid from the unit's home page. Twelve of the 18 had a link to financial aid, but it was somewhat "hidden" under such headings as "prospective students", "admissions", or even "offices." The challenge with this strategy or web design is that if the student and their parents and guardians, none of which have ever been to college, do not see financial aid, they could easily be discouraged and leave the site prior to finding the correct tab.

Financial aid is crucial for those trying to attend college. The lack of know-how to find ways to pay for college could set up a self-fulfilling prophecy that college is not affordable among low-income students, whether or not those students may actually qualify for substantial federal, state, and/or institutional financial aid (Green, 2005).

Table 2 shows that three of the 18 HBCUs did not even have a secondary link to financial aid on their unit's home page.

Table 2: Financial Aid/Scholarship Links

\begin{tabular}{lcc}
\multicolumn{3}{c}{ Table 2: Financial Aid/Scholarship Links } \\
\hline & $\frac{\text { Frequency }}{3}$ & $\frac{\text { Percent }}{16.7}$ \\
None & 12 & 66.7 \\
Present & 3 & 16.7 \\
Functional & & 100.0 \\
Total & & \\
\hline
\end{tabular}

\section{Course Descriptions and Listing}

The catalog has long been the primary source of information, containing vital information about the college, including general information, such as the university's mission and campus (Black, 2000, p. 15). Many colleges, much less HBCUs, could not afford to print all possible catalogues needed by those just wanting to find 
information about what classes are offered at the school. Course choice is important to a student. They like to see what courses are needed within a major. If they need to take extra math or foreign languages, for instance, is important for these students to know prior to making a college and major choice.

The unit's web page has the ability to take over and improve the traditional catalog. They can be interactive and, with a brief blurb, can inform a student precisely what the class requires from the professor. This study shows that HBCUs have at least taken some steps to address this need. Table 3 shows that 12 of the 18 units have some courses listed for the major. Eight of the 12 only list the courses, while four show descriptions of the courses. However, six of the total of 18 do not list courses needed for the major.

Table 3: Courses and Descriptions

\begin{tabular}{lcc}
\hline & Frequency & Percent \\
None & 6 & 33.3 \\
Present & 8 & 44.4 \\
Functional & 4 & 22.2 \\
Total & & 100.0 \\
\hline
\end{tabular}

\section{Graduation Roadmap}

The price of a four-year college education seems to have moved into a 4-1/2 to 5-year equation due to limits in class offerings (and those not being offered) because of budget cuts and other personnel issues. Schools with the 'roadmap to graduation' listing of all four years, broken down into semesters, help students see not only the core, but also the electives, and just when to take the classes in sequence. Students can then see if they may need summer courses and when they can do a study abroad or internship years ahead of time. Finding the right mixture is important. "Think of electives not as easy ways out, but as ideal ways to enhance your course of study with interests that make you happier and more well rounded" (Scheele, 2005, p. 49). This study was interested in seeing if HBCUs had the 'four-year plan' included on their units' websites.

Knowing what classes come, and in what order, is a way to help students succeed. Most undergraduate students need to prepare a schedule of courses for each term in which they plan to enroll and this schedule of classes must be approved by an academic advisor (Valverde, 2002, p. 120).

Table 4 shows HBCUs are not doing a good job of helping students be as prepared as they could be by not having the curriculum on their websites. Eleven of the 18 schools did not have their plan online and only five of the 18 had a complete proposed plan on their site.

Table 4: Course Schedule Graduation Map

\begin{tabular}{llc} 
& \multicolumn{3}{c}{ Table 4: Course Schedule Graduation Map } \\
\hline & Frequency & Percent \\
None & 11 & 61.1 \\
Present & 2 & 11.1 \\
Functional & 5 & 27.8 \\
Total & & 100.0 \\
\hline
\end{tabular}

\section{Social Media Links}

African-Americans have not only joined the social media craze, but they, along with Hispanics, lead the way in actual usage via computers and mobile devices. This study examined HBCU journalism/mass communication websites to see if they had any of the more popular social media as links on their home pages. For the purpose of this study, Facebook, Myspace, Twitter and RSS feeds were used. With more access to the Internet, usage on social media networks is to be expected as minorities and families with modest incomes continue to grow. African -Americans, along with middle-income families, are the major group responsible for the sharp rise in home 
broadband (Kenix, 2007). What this study found was the opposite in social media growth, at least with the HBCU websites themselves. Table 5 shows the depth of this situation, with 13 of the $18 \mathrm{HBCU}$ websites not having any of the social media platforms on their home pages and only one of the schools having all three of the social networks on its site.

Table 5: Social Media

\begin{tabular}{lcc}
\hline & Frequency & Percent \\
None & 13 & 72.2 \\
Present & 1 & 5.6 \\
Functional & 4 & 22.2 \\
Total & & 100.00 \\
\hline
\end{tabular}

\section{CONCLUSION}

Attention was paid to the selection of institutions in this study to ensure that they are representative of Historically Black Colleges and Universities, therefore allowing generalizations to be made that are valid. The exclusion to this pilot study regarding HBCUs was to not use single sex institutions.

Historically Black Colleges and Universities are vital to the overall success of America. They not only diversify the workforce, but also the nation's higher educational landscape, and also play a critical role in the lives of their students and within African-American communities that benefit culturally and economically from their presence (Brown \& Davis, 2001, p. 43). HBCUs are competing for students and using the Internet is a way to be even more inclusive in this marketing strategy. As the digital divide continues to shrink and African-Americans gain both computer literacy and access to the web, it is important for HBCUs to use the technology to recruit and continue their mission of nurturing and educating students who would otherwise not go to college. The factors that will end the discussion of a digital divide are long-standing issues in the African-American community - better education, a promotion of entrepreneurial culture, and access to capital (Dreyfuss, 2001).

HBCUs have done a good job of having individual unit web pages as a whole. Most of the sites have bits and pieces of what would be considered a usable page. It must be acknowledged that most colleges and universities work off of a universal template and cannot change their unit's overall look, but there are ways to work around any template to allow for better content.

HBCUs need to have more user-friendly websites. They need to make them simple and consist of relevant information, yet have it updated and as interactive as possible. Ultimately, users visit a website for its content; everything else is just the backdrop (Nielsen, 2000). Provide them with the information and with someone to contact via social media or email and not just fax or a phone number of the unit. Only four of the 18 HBCUs actually had a contact other than webmaster/unit. It was interesting to see that only five of the 15 have links to social media sites Facebook, Twitter, Myspace - or RSS feeds. This should change as soon as possible. One of their limitations may be for someone to monitor and respond, but it would be well worth the effort to have this option for people interested in the unit.

This pilot study monitored 18 of the 49 HBCUs that have units of journalism or mass communications to see if HBCUs are making full use of their websites in communicating who they are, what they can do, and who they educate. The findings indicate that HBCUs have, in general, not responded to the rising Internet usage by AfricanAmericans to promote their units and ease in the recruitment of students. A Pew group study (Spooner \& Rainie, 2004) found, among other things, that online African-Americans are $20 \%$ more likely than online Whites to have conducted school research or gotten job training on the Web.

HBCUs can use these results in better designing their websites to market to potential students and to better convey their mission and goals. In fact, one of the first things HBCUs should address is 'who they are' to anyone that goes to their site. This study found that only nine of the 18 schools had their mission statement on their home page. This is an important element to any successful business or school. What you say about yourself matters. Our 
mission statement speaks of the importance of formative development, service to society and state, and of a college's role in building stronger communities and a more vibrant democracy (Hartley \& Morphew, 2008). How families will pay for college is paramount in making a decision as to where the student will apply to attend school. How long will it take and how does the student matriculate through their four-year - or now even longer undergraduate degrees. HBCUs need to improve on placing this information prominently on their pages. Visitors to their site should not have to hunt for this information and HBCUs should not assume that everyone would just go to the admissions site to find it. HBCUs need to let the students know if there are any unit scholarships and list them along with the criteria in obtaining these funds.

HBCUs are doing a good job of being inclusive by using human images - both females and males - on their sites. They are also using different races to portray students in casual and professional settings.

The goal of having a website that has a high usability factor is not with a lot of flash or animation, but with clean and discernable text, information, and visuals that pay attention to download times. One of the main goals of great web design is to establish credibility as a professionally run operation (Nielsen, 2000).

Credibility is something that HBCUs bring to the table immediately. Now is the time to incorporate technology with tradition. By addressing the needs of prospective college students and by providing supplemental information about their schools and units, HBCUs will not only improve recruitment, but also help with any accrediting bodies that look for these same types of benchmarks.

College educators, high school guidance counselors, parents, guardians, and students can all benefit from these improvements.

\section{LIMITATIONS AND FUTURE RESEARCH}

There are only 49 Historically Black Colleges and Universities with journalism/mass communication units. This pilot study monitored 18 of these units. The study was a six-week long content analysis of their journalism/mass communication unit websites. The challenge of conceptualizing the variables used and not writing descriptions in the abstract allows for the researchers and others to further this pilot study in the future.

Future research should include all 49 institutions over a longer period of time, separating them into subgroups of size, cost, public or private, and even region. Research should also be conducted to include a survey of student perceptions of the HBCU websites. Interviews with unit governance, and possibly the institution's office of information, regarding any possible template demands should also be considered. Research on comparable Predominantly White Institutions (PWIs) should also be conducted with a focus on units with journalism and mass communications. There is a lack of studies that have been done to show the relationship between websites and enrollment in colleges and universities.

Future research should include three very important groups - prospective students, parents and guardians, and high school guidance counselors. These groups will provide great insight as to the assessment of the HBCU units' websites and also provide a rich texture of information regarding the uses and designs of the sites.

\section{AUTHOR INFORMATION}

Jerry Crawford is an assistant professor at the University of Kansas' William Allen White School of Journalism and Mass Communication. He has more than 25 years of professional experience in broadcast management. His research interests deal with the accreditation of colleges and universities, specifically Historically Black Colleges and Universities, with journalism and mass communication programs, and the ethical practices in broadcasting. Crawford teaches ethics, documentary and multimedia/convergence reporting and producing at Kansas. Crawford earned degrees at Virginia Commonwealth University, Virginia State University and Howard University. E-mail: jcrawford@ku.edu. 


\section{REFERENCES}

1. Allen, W. R., Jewell, J. O., Griffin, K. A., \& Wolf, D. S. (2007). Historically Black Colleges and Universities: Honoring the Past, Engaging the Present, Touching the Future. The Journal of Negro Education, 76(3), 263+.

2. Appiah, O. (2003). Americans Online: Differences in Surfing and Evaluating Race-Targeted Web Sites by Black and White Users. Journal of Broadcasting \& Electronic Media, 47(4), 537+.

3. Atkinson, R. C., \& Pelfrey, P. A. (2006). Opportunity in a Democratic Society: Race and Economic Status in Higher Education1. Proceedings of the American Philosophical Society, 150(2), 318+.

4. Bell, A. D., Rowan-Kenyon, H. T., \& Perna, L. W. (2009). College Knowledge of 9th and 11th Grade Students: Variation by School and State Context. Journal of Higher Education, 80(6), 663+.

5. Bell, D., Loader, B. D., Pleace, N., \& Schuler, D. (2004). Cyberculture: The Key Concepts. London: Routledge.

6. Bers, T. H., \& Galowich, P. M. (2002). Using Survey and Focus Group Research to Learn about Parents' Roles in the Community College Choice Process. Community College Review, 29(4), 67+.

7. Black, I. (Ed.). (2000). African-American Student's College Guide: Your One-Stop Resource for Choosing the Right College, Getting In, and Paying the Bill. New York: Wiley.

8. Brown, M. C., \& Davis, J. (2001). The Historically Black College as Social Contract, Social Capital, and Social Equalizer. In Access and Equity in Postsecondary Education, Brown, M. C. (Ed.) (pp. 31-47). Mahwah, NJ: Lawrence Erlbaum Associates.

9. Brown, M. C. \& Freeman, K. (Eds.). (2004). Black Colleges: New Perspectives on Policy and Practice. Westport, CT: Praeger.

10. Calandra, B., \& Barron, A. E. (2005). A Preliminary Investigation of Advance Organizers for a Complex Educational Website. Journal of Educational Multimedia and Hypermedia, 14(1), 5+.

11. Camp, D. V., Barden, J., Sloan, L. R., \& Clarke, R. P. (2009). Choosing an Hbcu: an Opportunity to Pursue Racial Self-development. The Journal of Negro Education, 78(4), 457+.

12. Crawford, J, \& Hines, B. (2010). Earning accreditation and preparing students for future challenges: journalism education at historically black colleges. In B. Franklin (Ed.), Journalism education, training and employment (pp. 48-68). New York, NY: Routledge.

13. Daigneault, S. D., \& Wirtz, E. (2008). Before the Pomp and Circumstance: Seniors Reflect on Graduating from High School. Professional School Counseling, 11(5), 327+.

14. Davis, J. A. (1965). Undergraduate Career Decisions: Correlates of Occupational Choice. Chicago: Aldine Publishing.

15. Denscombe, M. (2007). The Good Research Guide: For Small-Scale Social Research Projects (3rd ed.). Maidenhead, England: Open University Press.

16. Dreyfuss, J. (2001, January 1). Black Americans and the Internet: the Technological Imperative. National Urban League. The State of Black America 131+.

17. Ekins, R. (1997). Male Femaling: A Grounded Theory Approach to Cross-Dressing and Sex-Changing. London: Routledge.

18. Elam, C., \& Brown, G. (2005). The Inclusive University: Helping Minority Students Choose a College and Identify Institutions That Value Diversity. Journal of College Admission, (187), 14+.

19. Evans, A., Evans, V., \& Evans, A. (2002). Historically Black Colleges and Universities. Education, 123(1), $3+$.

20. Feeney, N. (2009). Getting Personal: How Colleges and High School Students Connect Online. Journal of College Admission, (203), 4+.

21. Feldman, G. (2000). The Dark Side of the Internet: Divided about the Digital Divide. The Public Manager, 29(4), 55.

22. Flowers, L. A., \& Zhang, Y. (2003). Racial Differences in Information Technology Use in College. College Student Journal, 37(2), 235+.

23. Gifford, D., Briceño-Perriott, J., \& Mianzo, F. (2005). Pen to Mouse: Web-based Technology's Impact on College Admission Applications. Journal of College Admission, (188), 16+.

24. Green, T. C. (2005). Financial Aid, Access and America's Social Contract with Higher Education. College and University, 80(3), $9+$. 
25. Hartley, M., \& Morphew, C. C. (2008). What's Being Sold and to What End? A Content Analysis of College Viewbooks. Journal of Higher Education, 79(6), 671+.

26. Jackson, L. A., Von Eye, A., Biocca, F., Barbatsis, G., Zhao, Y., \& Fitzgerald, H. E. (2005). How LowIncome Children Use the Internet at Home. Journal of Interactive Learning Research, 16(3), $259+$.

27. Jensen, K, \& Jankowski, N. (Ed.). (1991). A handbook of qualitative methodologies for mass communication research. New York, NY: Routledge.

28. Judge, S. (2005). The Impact of Computer Technology on Academic Achievement of Young AfricanAmerican Children. Journal of Research in Childhood Education, 20(2), 91+.

29. Kenix, L. J. (2007). The Homogenized Imagery of Non-profit Organizations on the Internet. Visible Language, 41(2), 127+.

30. Koh, W. T., \& Leung, H. (1992). Persuasive Advertising and Market Competition. American Economist, $36(2), 39+$.

31. Malroutu, Y. L., \& Tripp, P. J. (2008). Proactive Recruitment Strategies at Csus Increase Fcs Majors. Journal of Family and Consumer Sciences, 100(1), 18+.

32. Marcus, M. (2011, June). Minority kids spend most of their waking hours plugged in. Retrieved from http://yourlife.usatoday.com/parenting-family/story/2011/06/Minority-kids-spend-most-of-their-wakinghours-plugged-in-/48172486/1?loc=interstitialskip

33. Mastin, T. (2000). Media Use and Civic Participation in the African-American Population: Exploring Participation among Professionals and Nonprofessionals. Journalism and Mass Communication Quarterly, 77(1), 115+.

34. Moriarty, S. E. (1996). The Circle of Synergy: Theoretical Perspectives and an Evolving Imc Research Agenda. In Synergy of Persuasive Voices Synergy of Persuasive Voices, Thorson, E. \& Moore, J. (Eds.) (pp. 333-349). Mahwah, NJ: Lawrence Erlbaum Associates.

35. Morphew, C. C., \& Hartley, M. (2006). Mission Statements: A Thematic Analysis of Rhetoric across Institutional Type. Journal of Higher Education, 77(3), 456+.

36. Nielsen, J. (2000). Designing web usability. Indianapolis, IN: New Riders Publishing.

37. Ng, C. K., Parette, P., \& Sterrett, J. (2003). Evaluation of a Graduate School Web-Site by Graduate Assistants. College Student Journal, 37(2), 242+.

38. O'Callaghan, C., \& Hiscock, R. (2007). Interpretive Subgroup Analysis Extends Modified Grounded Theory Research Findings in Oncologic Music Therapy. Journal of Music Therapy, 44(3), 256+.

39. Perna, L. W. (2000). Differences in the Decision to Attend College among African-Americans, Hispanics and Whites. Journal of Higher Education, 71(2), 117.

40. Peters, V.A. and Wester, F.P. (1990). Qualitative analysis in practice. Catholic University

41. Pomering, A., \& Johnson, L. W. (2009). Constructing a Corporate Social Responsibility Reputation Using Corporate Image Advertising. Australasian Marketing Journal, 17(2), 106+.

42. Poock, M. C. (2006). Characteristics of an Effective Web Site in Educational Leadership. College Student Journal, 40(4), 785+.

43. Poock, M. C., \& Lefond, D. (2001). How College-bound Prospects Perceive University Web Sites: Findings, Implications, and Turning Browsers into Applicants. College and University, 77(1), 15+.

44. Richardson, J. W. (2008). Demystifying and Deconstructing the College Application Process. The Journal of Negro Education, 77(4), 382+.

45. Rufo, K. (2003). Rhetoric and Power: Rethinking and Relinking. Argumentation and Advocacy, $40(2)$, iiit.

46. Scheele, A. M. (2005). Launch Your Career in College: Strategies for Students, Educators, and Parents. Westport, CT: Praeger.

47. Shelby, A. N. (1998). Communication Quality Revisited: Exploring the Link with Persuasive Effects. The Journal of Business Communication, 35(3), 387+.

48. Sissoko, M., \& Shiau, L. (2005). Minority Enrollment Demand for Higher Education at Historically Black Colleges and Universities from 1976 to 1998: An Empirical Analysis. Journal of Higher Education, 76(2), $181+$.

49. Smith, A. (2010, July 7). Mobile access 2010. Retrieved from http://www.pewinternet.org/Reports/2010/Mobile-Access-2010/Summary-of-Findings.aspx

50. Spooner, T., \& Rainie, L. (2004). African-Americans and the Internet. Pew Online Report. Retrieved July 9, 2010. From http://www.pewinternet.org/Reports/2000/AfricanAmericans-and-theInternet/Summary.aspx 
51. Starkman, N. (2006). If You Build It Right, They Will Come: Easy-to-Use Content Management Systems Are Helping Schools and Districts Create Websites That Appeal to the Eye-And to Users. T H E Journal (Technological Horizons In Education), 33(1), 20+.

52. Tapia, A., \& Ortiz, J. A. (2008). Deploying for Deliverance: the Digital Divide in Municipal Wireless Networks. Sociological Focus, 41(3), 256+.

53. Tierney, W. G., \& Venegas, K. M. (2009). Finding Money on the Table: Information, Financial Aid, and Access to College. Journal of Higher Education, 80(4), 363+.

54. Tobolowsky, B. F., Outcalt, C. L., \& McDonough, P. M. (2005). The Role of Hbcus in the College Choice Process of African-Americans in California. The Journal of Negro Education, 74(1), 63+.

55. Valverde, L. A. (Ed.). (2002). The Latino Student's Guide to College Success. Westport, CT: Greenwood Press.

56. Zimmerman, J. N., \& Meyer, A. (2005). Building Knowledge, Building Community: Integrating Internet Access to Secondary Data as Part of the Community Development Process. Journal of the Community Development Society, 36(1), 93+. 
NOTES 